\title{
Hubungan kadar zink dan kenaikan berat badan ibu hamil dengan berat badan bayi lahir di RSUD Curup Kabupaten Rejang Lebong Propinsi Bengkulu
}

\author{
Ade Wahyulian Wijaksono ${ }^{1}$, Rosfita Rasyid ${ }^{2}$, Rinang Mariko ${ }^{3}$ \\ 1. Puskesmas Kota Donok; 2. Fakultas Kedokteran Universitas Andalas; 3. Bagian Ilmu Kesehatan \\ Anak RSUP dr. M. Djamil Padang
}

Korespondensi: Ade Wahyulian Wijaksono,email:wijaksono73@gmail.com

\begin{abstract}
Abstrak
Berat badan lahir bayi merupakan salah satu penanda asupan gizi ibu selama kehamilan. Zink adalah salah satu mikronutrien penting untuk fungsi sejumlah enzim dan hormon pertumbuhan. Defisiensi zink dan kenaikan berat badan selama kehamilan yang kurang dari normal dapat menyebabkan berat badan lahir rendah. Tujuan: Untuk mengetahui hubungan kadar zink dan kenaikan berat badan ibu selama kehamilan dengan berat badan lahir bayi. Metode: Desain penelitian ini adalah cross-sectional, observasi pada 39 orang ibu yang pada waktu hamil trimester III pernah datang memeriksakan kehamilannya dan tercatat telah melahirkan di RSUD Curup, Kabupaten Rejang Lebong, Provinsi Bengkulu. Kadar zink diperiksa di Balai Laboratorium Kesehatan Sumatera Barat dengan immunoassay, dan kenaikan berat badan ibu hamil diperiksa dengan mengukur selisih berat badan trimester III dengan sebelum kehamilan. Hasil: Didapatkan rerata kadar zink ibu hamil aterm adalah $60,35 \pm 39,16$ $\mu \mathrm{g} / \mathrm{dL}$; rerata kenaikan berat badan ibu hamil aterm adalah 11,59 $\pm 5,95 \mathrm{~kg}$; dan rerata berat badan lahir bayi $3002,56 \pm 580,60 \mathrm{gr}$. Terdapat korelasi sangat kuat antara kadar zink dan kenaikan berat badan ibu hamil aterm dengan berat badan lahir bayi, dengan nilai $p=0,000$ dan $r=0,879$. Simpulan: Nilai korelasi ( $r$ ) yang positif menunjukkan bahwa semakin tinggi kenaikan berat badan ibu hamil, maka diperkirakan berat badan bayi yang dilahirkan semakin besar, dan sebaliknya.
\end{abstract}

Kata kunci: kadar zink; kenaikan berat badan; berat badan lahir bayi

\begin{abstract}
Birth weight is one of the markers of mother's nutritional intake during pregnancy. Zinc is an essential micronutrient for number of enzymes function and growth hormone. Zinc deficiency and weight gain less than normal can cause low birth weight. Objective: To determine the relationship of zinc levels and increase in maternal body weight during pregnancy with the baby's birth weight. Methods: The design of this study was cross sectional, observe 39 women in third trimester of pregnancy had checked and have given birth in RSUD Curup, Kabupaten Rejang Lebong, Bengkulu. Zinc concentration was checked at Balai Laboratorium Kesehatan Sumatera Barat by immunoassay, and weight gain by measuring the difference of third trimester before pregnancy. Results: We obtained, mean concentration of maternal zinc is $60.35 \pm 39.16 \mu \mathrm{g} / \mathrm{dL}$; mean of maternal weight gain is $11.59 \pm 5.95 \mathrm{~kg}$; and mean of birth weight is $3002.56 \pm 580.60 \mathrm{gr}$. There was very strong correlation between maternal zinc concentration with birth weight, with $p=0.000$ and $r=0.879$. The positive correlation value ( $r$ ) showed that the higher maternal zinc concentration, the bigger birth weight, and vice versa. Conclusion: The positive correlation value ( $r$ ) showed that the higher maternal weight gain, the higher birth weight, and vice versa.
\end{abstract}

Keywords: zinc concentration; weight gain; birth weight 


\section{PENDAHULUAN}

Berat badan lahir bayi merupakan salah satu penanda asupan gizi ibu selama kehamilan. Permasalahan yang banyak terjadi saat ini adalah tingginya angka kematian bayi khususnya pada masa perinatal yang dikarenakan bayi lahir dalam keadaan Berat Badan Lahir Rendah (BBLR). Pada tahun 2014, prevalensi BBLR dunia sebanyak 15\%, tertinggi di Asia Selatan yaitu sebesar $28 \%$, Asia Timur dan Pasifik hanya 6\%, Amerika Latin 9\%, serta Afrika dan negara ketiga lainnya $13 \%{ }^{1}$

Data Riset Kesehatan Dasar (Riskesdas) tahun 2013 menunjukkan persentase BBLR di Indonesia 10,2\%, lebih rendah dari tahun 2010; 11,1\%. Persentase BBLR tertinggi di Sulawesi Tengah (16,9\%) dan terendah di Sumatera Utara (7,2\%), sedangkan di Bengkulu terjadi peningkatan dari tahun 2010, yaitu dari sekitar 9\% menjadi $10 \%$, di tahun $2013 .^{2}$

Status gizi ibu dipengaruhi oleh besaran asupan energi yang terdiri dari karbohidrat, protein, zat besi, asam folat, vitamin A, zink, kobalamin, vitamin D, yodium, kalsium, dan zat gizi lainnya. Zink merupakan salah satu mikronutrien esensial bagi manusia, yang secara alami terdapat pada beberapa makanan. Zink merupakan kofaktor lebih dari 100 enzim dan penting untuk metabolisme asam nukleat dan sintesis protein. Zink berperan dalam pertumbuhan, perkembangan, dan diferensiasi sel. ${ }^{3,4}$

Zink penting untuk fungsi sejumlah enzim dan hormon pertumbuhan selama kehamilan. Pada ibu hamil, konsentrasi zink relatif menurun hingga 35\% karena pengaruh perubahan hormon dan transpor nutrisi dari ibu ke bayi. Kandungan zink yang rendah pada ibu hamil mengurangi transpor nutrisi ke rahim dan mempengaruhi penyediaan gizi yang memadai ke bayi. Defisiensi zink selama kehamilan dapat menimbulkan berat badan lahir rendah, Intrauterine Growth Restriction (IUGR), kehamilan preterm, serta komplikasi lainnya. ${ }^{5}$

Penelitian ini bertujuan untuk mengetahui hubungan kadar zink dan kenaikan berat badan ibu selama kehamilan dengan berat badan lahir bayi.

\section{METODE}

Penelitian ini merupakan suatu studi observasional dengan desain crosssectional, untuk mengetahui hubungan kadar zink dan kenaikan berat badan ibu selama kehamilan dengan berat badan lahir bayi di RSUD Curup, Kabupaten Rejang Lebong, Provinsi Bengkulu dari bulan Mei s/d Juni 2018 untuk mengumpulkan sampel dan di Balai Laboratorium Kesehatan Dinas Kesehatan Provinsi Sumatra Barat untuk memeriksa kadar zink.

Populasi pada penelitian ini adalah seluruh ibu yang pada waktu hamil trimester III pernah datang memeriksakan kehamilannya dan tercatat telah melahirkan di ruang bersalin RSUD Curup, Kabupaten Rejang Lebong, Provinsi Bengkulu dari tanggal 21 Mei s/d 30 Juni 2018. Besar sampel minimal adalah 35 
pasang ibu dan bayi. Jika diperkirakan drop out $10 \%$, maka besar sampel menjadi 39 pasang ibu dan bayi. Pemilihan sampel dilakukan dengan cara consecutive sampling, yang dilakukan di ruang bersalin RSUD Curup, Kabupaten Rejang Lebong, Propinsi Bengkulu dari tanggal $21 \mathrm{Mei} \mathrm{s/d}$ 30 Juni 2018.

Sampel pada penelitian ini adalah bagian dari populasi yang sesuai dengan kriteria inklusi: (1) memiliki data berat badan sebelum kehamilan yang tercatat di buku KIA, (2) ibu bersalin dengan kehamilan aterm, tunggal, dan bayi normal lahir hidup, (3) bersedia ikut dalam penelitian dan kooperatif; dan kriteria eksklusi: (1) bayi dengan kelainan kongenital, (2) pada kehamilan pernah didiagnosis diabetes, tuberkulosis, malaria, hipertensi, atau preeklampsia, (3) tidak dapat mengikuti prosedur pemeriksaan yang ditetapkan.

Dilakukan pencatatan nama dan usia, serta dilakukan anamnesis dan pemeriksaan fisik untuk menyingkirkan berbagai hal yang termasuk dalam kriteria eksklusi. Ditimbang berat badan ibu hamil pada ANC di trimester III dan dibandingkan dengan berat badan sebelum hamil. Diambil sampel darah ibu sebanyak $3 \mathrm{ml}$ menggunakan spuit disposibel 3cc sebelum melahirkan, setelah itu dimasukkan ke dalam tabung centrifuge warna gold yang mengandung gel, didiamkan disuhu ruangan selama 30 menit, setelah itu dilakukan centrifuge selama 15 menit dengan kecepatan 3000 rpm.

Diikuti proses kelahiran dan menimbang berat badan bayi yang dilahirkan dalam satu jam pertama kelahiran. Berat badan bayi ditimbang dan dicatat di rekam medis. Dilakukan pemisahan serum menggunakan mikro pipet, masukan ke dalam tabung effendorf 1,5 $\mathrm{ml}$, dan simpan di kulkas vaksin dengan suhu antara $2^{\circ} \mathrm{C}-8^{\circ} \mathrm{C}$.

Dilakukan pemeriksaan kadar zink serum menggunakan teknik Atomic Absorption Spectrophotometry (AAS) di Balai Laboratorium Kesehatan Dinas Kesehatan Provinsi Sumatra Barat.

\section{HASIL DAN PEMBAHASAN}

Hasil penelitian didapatkan rerata kadar zink ibu hamil aterm adalah 60,35 $\pm 39,16$ $\mu \mathrm{g} / \mathrm{dL}$; rerata kenaikan berat badan ibu

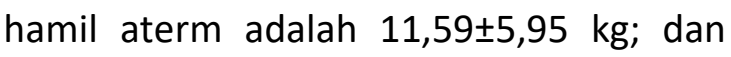
rerata berat badan lahir bayi $3002,56 \pm 580,60$ gram.

Tabel 1. Rerata kadar zink dan kenaikan berat badan ibu hamil aterm serta berat bayi yang dilahirkan

\begin{tabular}{lllll}
\hline Variabel & Rerata \pm SD & Median & Min & Max \\
\hline Zink $(\mu \mathrm{g} / \mathrm{dL})$ & $60,35 \pm 39,16$ & 54,80 & 21,60 & 243,20 \\
Kenaikan BB $(\mathrm{kg})$ & $11,59 \pm 5,95$ & 10,00 & 4,00 & 26,00 \\
Berat bayi $(\mathrm{gram})$ & $3002,56 \pm 580,60$ & $3.000,00$ & $2.200,00$ & $4.000,00$ \\
\hline
\end{tabular}

Ibu hamil sangat rentan terhadap defisiensi zink, diperkirakan sekitar $82 \%$ di dunia, dan paling banyak terjadi di negara-negara berkembang, termasuk Indonesia.
Kebutuhan zink pada ibu hamil diperkirakan sekitar 60-130 $\mathrm{\mu g} / \mathrm{dL}$. Pada penelitian ini, lebih dari sebagian sampel yang ada mengalami defisiensi zink. ${ }^{6}$ 
Konsentrasi zink pada ibu hamil relatif menurun hingga 35\% karena pengaruh perubahan hormon dan transpor nutrisi dari ibu ke bayi. Kandungan zink yang rendah pada ibu hamil akan mengurangi transpor nutrisi ke janin dan mempengaruhi penyediaan gizi yang memadai bagi janin. ${ }^{7}$

Selain kadar zink, juga dibahas mengenai kenaikan berat badan yang merupakan salah satu indikator seorang ibu berisiko mengalami KEK atau tidak. Laporan Riskesdas 2013 menyatakan prevalensi KEK pada wanita hamil masih cukup tinggi, yaitu sebesar $24,2 \%{ }^{8}$

Kadar zink dan kenaikan berat badan ibu hamil memiliki pengaruh terhadap kejadian BBLR. Prevalensi BBLR di Indonesia sekitar 10,2\%. Kabupaten Rejang Lebong merupakan daerah dengan BBLR terbanyak se-provinsi Bengkulu, yaitu sebanyak $2,3 \%{ }^{9}$

Analisis hubungan antara kadar zink ibu hamil aterm dengan berat badan lahir bayi menggunakan uji korelasi Spearman, signifikan bila $p<0,050$. Dari hasil analisis tampak adanya hubungan yang signifikan antara kadar zink ibu hamil aterm dengan berat badan bayi yang dilahirkannya, dengan arah hubungan positif, $(p=0,000$; $r=0,879$ ). Kadar zink ibu hamil sebesar 0,879\% mempengaruhi berat badan lahir. Dengan demikian, dapat diartikan ibu dengan kadar zink yang normal akan melahirkan bayi dengan berat badan normal, begitu juga sebaliknya. ${ }^{10}$
Peran zink pada ibu hamil adalah untuk mendukung tumbuh kembang janin di dalam rahim hingga lahir dan tumbuh hingga masa balita dan anak-anak. Zink penting untuk fungsi kekebalan tubuh. Defisiensi zink selama kehamilan dapat menyebabkan retardasi pertumbuhan pada janin melalui pengaruhnya terhadap perkembangan sistem imun. Zink berperan mengatur aktivitas IGF-1 dalam membentuk osteoblas, yang diketahui berfungsi penting bagi pertumbuhan tulang. Berbagai enzim dan hormon pertumbuhan, yang berperan penting bagi pertumbuhan postnatal, membutuhkan zink selama kehamilan. Sebagai contoh, placental alkaline phosphatase yang merangsang sintesis DNA dan proliferasi sel saat kehamilan. ${ }^{11}$

Hasil analisis tampak adanya hubungan yang signifikan antara kenaikan berat badan ibu hamil aterm dengan berat badan bayi yang dilahirkannya, dengan arah hubungan positif, ( $p=0,000 ; r=0,882)$. Dengan demikian, ibu dengan kenaikan berat badan normal akan melahirkan bayi dengan berat badan normal juga, dan sebaliknya. Hal ini sesuai dengan yang didapatkan Lagiou (2004), yaitu terdapat hubungan positif antara pertambahan berat badan ibu selama kehamilan dengan berat badan bayi yang dilahirkan. ${ }^{12}$

Asupan nutrisi selama kehamilan merupakan hal yang sangat penting. Ini berguna untuk memenuhi kebutuhan energi ibu, supply nutrisi ke uterus dan plasenta, serta nutrisi bagi janin. Akibatnya 
akan terjadi kenaikan berat badan ibu selama kehamilan.

Wanita dengan berat badan rendah sebelum kehamilan atau berat badan rendah yang diperoleh selama kehamilan mempunyai risiko tinggi melahirkan bayi BBLR. Akan tetapi, jika memiliki kebiasaan makan yang baik dan mempunyai berat badan normal sebelum kehamilan, maka tidak akan mengalami masalah selama kehamilan, termasuk risiko melahirkan bayi BBLR. ${ }^{13}$

Ibu dengan pertambahan berat badan yang kurang dari normal selama kehamilan akan memberikan dampak bagi janin berupa gangguan pertumbuhan dan fungsi plasenta, yang terlihat dari berat dan ukuran plasenta yang relatif lebih kecil. Selain itu, gizi yang tidak memadai pada ibu hamil juga akan mengurangi volume darah yang dialirkan, akibatnya darah yang dipompa dari jantung tidak dapat mencukupi kebutuhan semestinya. Hal ini akan mengurangi aliran darah ke plasenta, sehingga ukuran plasenta tidak optimal serta zat gizi yang diangkut ke janin pun berkurang. Akibatnya, pertumbuhan janin akan terhambat. ${ }^{14}$

Keterbatasan penelitian ini adalah yaitu jumlah sampel darah yang bisa di ambil dari responden maksimal hanya sebanyak $4 \mathrm{cc}$, dikarenakan responden berkeberatan untuk dilakukan tindakan pengambilan darah sebanyak dua kali dengan alasan ketidaknyamanan (perih/sakit), sehingga tidak bisa dari satu orang responden dibuat jadi dua serum yang tujuannya adalah untuk serum cadangan jika terjadi kesalahan pemeriksaan laboratorium.

\section{SIMPULAN}

Dari penelitian ini dapat diambil simpulan bahwa semakin tinggi kadar zink ibu hamil aterm maka akan semakin tinggi pula berat badan lahir bayi. Dan semakin tinggi kenaikan berat badan ibu hamil aterm maka akan semakin tinggi pula berat badan lahir bayi.

\section{DAFTAR PUSTAKA}

1. World Health Organization. WHA global nutrition targets 2025: low birth weight policy brief', Global Targets 2025. Geneva: WHO; 2014.

2. Kementerian Kesehatan RI. Riset Kesehatan Dasar 2013. Jakarta: Kementerian Kesehatan RI; 2013.

3. Arisman. Gizi dalam daur kehidupan. Jakarta: EGC; 2010.

4. Hirano T. Roles of zinc signaling in immunity: zinc as intracellular signaling molecule. Adv Immunol. 2008; 97:149-176.

5. Agustian L, Sembiring T, Ariani A. Peran zinkum terhadap pertumbuhan anak. Sari Pediatri. 2009; 11:244-249.

6. Herman S. Review on the problem of zinc deficiency, program prevention and its prospect. Media Penelitian dan Pengembangan Kesehatan. 2009; 19:s75-83. 
7. Karimi A, Bgheri S, Nematy $M$, Sae $M$. Zinc deficiency in pregnancy and fetal impact of the supplements on pregnancy outcomes. Iranian Journal of Neonatology. 2012; 3(2):77-83. doi: $10.22038 /$ IJN.2012.270.

8. Lubis Z. Status gizi ibu hamil serta pengaruhnya terhadap bayi yang dilahirkan. Bogor: IPB Press; 2003.

9. Dinas Kesehatan Provinsi Bengkulu. Profil Kesehatan Provinsi Bengkulu Tahun 2015. Bengkulu: Dinas Kesehatan Provinsi Bengkulu; 2016.

10. Wang H, Hu YF, Hao JH, Chen YH, Su PY, Wang Y, et al. Maternal zinc deficiency during pregnancy elevates the risks of fetal growth restriction: a population-based birth cohort study. Scientific Reports. 2015; 5:11262. doi: 10.1038/srep11262.

11. Mori R, Ota E, Middleton P, Tobe-Gai R, Mahomed K, Bhutta ZA. Zinc supplementation for improving pregnancy and infant outcome. Cochrane Database Syst Rev. 2012; 7: CD000230. doi: 10.1002/14651858.CD000230.pub4.

12. Lagiou P, Tamimi RM, Mucci LA, Adami HO, Hsieh CC, Trichopoulos D. Diet during pregnancy in relation to maternal weight gain and birth size. Eur J Clin Nutr. 2004; 58(2):231-7. doi: 10.1038/sj.ejcn.1601771.

13. Jaya N. Analisis faktor resiko kejadian bayi berat lahir rendah di rumah sakit ibu dan anak Siti Fatimah Kota Makassar. Media Gizi Pangan. 2009; 7:49-54.

14. Karima K, Achadi EL. Status gizi ibu dan berat badan lahir bayi. Jurnal Kesehatan Masyarakat. 2012; 7:111-119. 